\title{
Exfoliative cytology and autoradiography using ${ }^{32} \mathrm{P}$
}

\author{
A. M. BAPTISTA, A. L. BASTOS, AND M. E. SILVESTRE \\ From the Isotope Laboratory, Portuguese Cancer Institute, the Department of \\ Medicine, Medical School of Lisbon, and the Department of Radiotherapy, Portuguese Cancer \\ Institute, Palhava, Lisbon, Portugal
}

In an excellent review of the medical applications of radioactive phosphorus, Kamen (1951) has discussed the evidence suggesting that malignant tissue differs from normal cells in showing a higher incorporation of the isotope into nuclear components. The increased uptake of ${ }^{32} \mathrm{P}$ by the nucleoproteins of tumour cells is probably related to their increased mitotic activity and many attempts have been made to use radiophosphorus uptake as a criterion in the differentiation of benign from malignant growths (Ackerman, McFee, Bhum, Makowski, and Wangensteen, 1963). This paper describes a procedure for distinguishing a squamous malignant cell from a normal epithelial cell. The cells are obtained by the accepted techniques of exfoliative cytology, incubated in vitro with the radiophosphorus, and the intracellular accumulation of the isotope is assessed by autoradiography.

\section{MATERIAL AND METHODS}

The procedure used in exfoliative cytology was that described by Raskin, Kirsner, Palmer, Pleticka, and Yarema (1958). Cancer was proved in 10 out of the 12 patients in whom this procedure was carried out.

The patient sat in an upright position and a Levine tube (no. 18) was inserted either down to the $45 \mathrm{~cm}$. mark or to the region where the lesion was suspected. Two washings, each of 40 to $50 \mathrm{ml}$., with Ringer's solution were made from a $100 \mathrm{ml}$. syringe. The tube was successively withdrawn for $5 \mathrm{~cm}$. each time and the washings repeated until all the oesophagus was considered to have been sampled. The saline washes, preserved on ice, were bulked and centrifuged for three minutes at 3,600 r.p.m. Part of the centrifuged sediment was spread on a frosted slide. The remainder was mixed with $0 \cdot 2$ to $20 \mu \mathrm{c}$. of radioactive sodium orthophosphate per millilitre (from the Radiochemical Centre, Amersham, Bucks.). The mixtures were incubated at $37^{\circ} \mathrm{C}$. for $30 \mathrm{~min}$. in a water-bath, centrifuged as before, and the cellular sediment washed four times with $20 \mathrm{ml}$. of Ringer's solution to remove any ${ }^{32} \mathrm{P}$ not incorporated into the cells. The final sediment was spread on a microscope slide coated with gelatin film and immersed in a fixative solution ( $95 \%$ ethanol and ether, 1:1) for 15 to 30 minutes. A similar procedure was performed with a suspension of sarcoma 37 cells except that one portion of the sarcoma cells was incubated as above but without the labelled phosphate to act as a control.

The tumour cells of the sarcoma 37 came from the National Institute of Cancer (U.S.A.) and were maintained through successive subcutaneous inoculations in the right posterior leg of white Swiss mice. As a result of these injections mice developed a subcutaneous solid tumour.

The cell suspension was obtained by intratumoural lavage with saline solution.

After fixation, the cytological material was exposed to Kodak AR-10 film for 24 hours using the stripping-film technique of Pelc (personal communication).

\section{RESULTS}

Using $20 \mu \mathrm{c}$. of radioactive phosphate and keeping the radioactive solution between 0.2 and $0.3 \mathrm{ml}$., it was possible to label squamous cells in all stages varying from the basal and parabasal cells to the mature cells. However, not all the normal cells could be visualized in this way, and with this amount of radioactivity the cancer cells incorporated so much ${ }^{32} \mathrm{P}$ that the autoradiographs were too dense for individual cells to be recognized. Similar results were obtained with the sarcoma 37 cells and in the corresponding control experiments, i.e., those incubated without radioactive phosphate, no incorporation of radioactivity by the cells was detected by autoradiography. The use of Papanicolaou staining methods, before and after autoradiography, did not prove feasible because the staining did not survive the subsequent processing of the films.

When $0.2 \mu \mathrm{c}$. of labelled phosphate was used, the sarcoma 37 cells produced a barely perceptible amount of radioactivity around the nuclear membrane. With $2 \mu \mathrm{c}$. of radioactive phosphate there were large and unmistakable incorporations of ${ }^{32} \mathrm{P}$ in the malignant cells (Figs. 1a and 1b) whereas the normal cells showed only minor amounts of incorporated isotope.

With the fluorescent microscope it was possible to recognize the cancer cells which had taken up ${ }^{32} \mathrm{P}$ by the criteria of fluorescent cytology (Bertalanffy, Masin, and Masin, 1958). Using the vernier coordinates of a graduated mechanical stage, the 


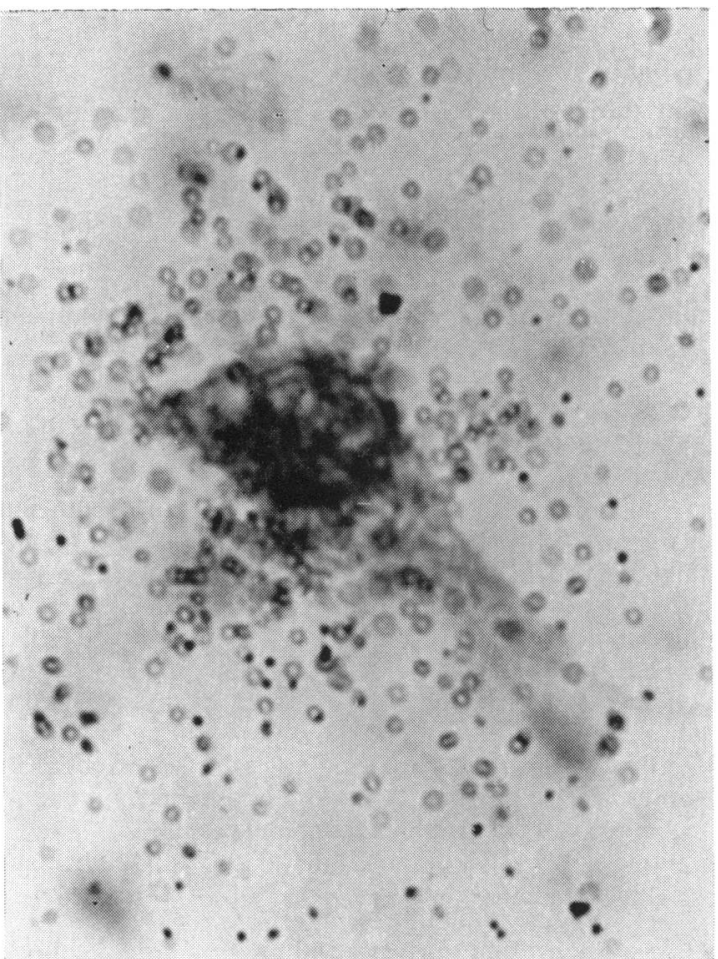

FIG. 1a

FIG. 1a. Cancer cell of oesophagus (tadpole cell).

FIG. 1b. Same field but focused at emulsion layer of the autoradiograph film (autoradiograph obtained after incubation with ${ }^{32} P$, about $2 \mu c$. and 24 hour's exposure) 1,500:1.

same cells were observed after the autoradiographic procedure. Autoradiographic images were observed in the positions where the fluorescent dye had previously shown the positions of the malignant cells.

In these experiments it was observed that the incorporation of radiophosphorus by the cancer cells was not uniform and this probably depends on the different phases of mitotic activity shown by the cells.

\section{SUMMARY}

Employing the technique of exfoliative cytology, it is possible to observe after an incubation with ${ }^{32} \mathrm{P}$ $(2 \mu \mathrm{c}$. per 24 hours' exposure) that oesophageal cancer cells in vitro have a much higher radionuclide uptake than normal cells as revealed by autoradiography. Since the differential uptake is so high, 'cytoautoradiography', as this procedure might be named, might prove useful in the study and identification of the single malignant cell. No attempt was made to compare the results of autoradiographic and exfoliative cytological studies.

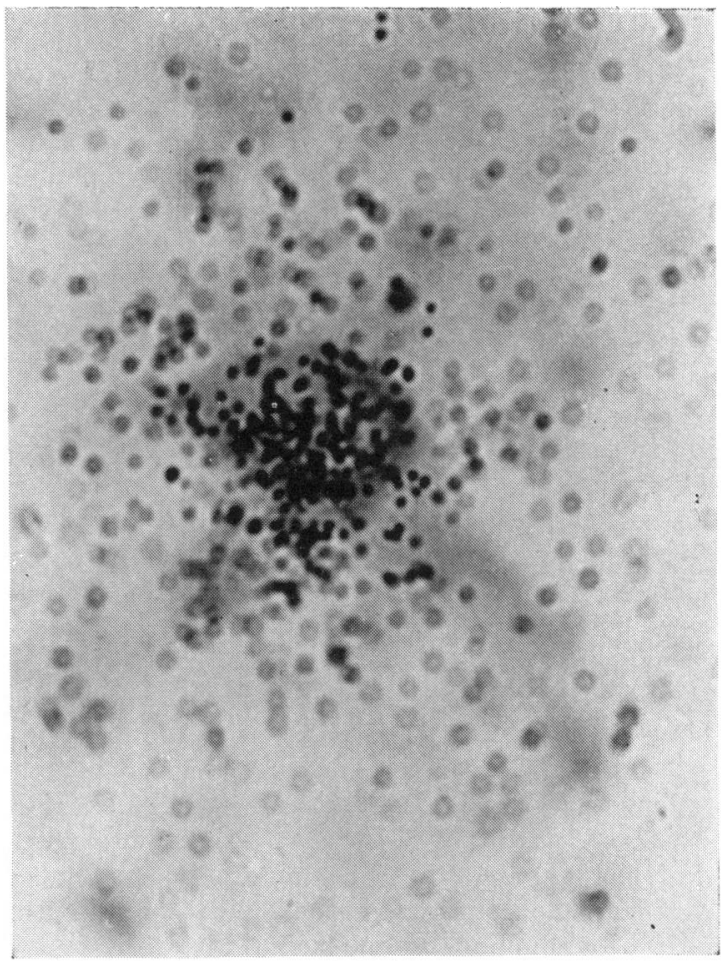

FIG. $1 \mathrm{~b}$
An interesting correlation was the observation on fixed cancer cells between nucleic acid (R.N.A./ D.N.A.) concentration as shown by acridine orange fluorescent techniques and the increased uptake of ${ }^{32} \mathrm{P}$ by the same cancer cells.

We wish to thank Professor Frederico Madeira for all the facilities obtained and for his interest in this work. We are equally indebted to Dr. William Clode of the Laboratório de Isótopos Abílio Lopes do Rego at the Instituto Português de Oncologia for the sarcoma 37 cells.

\section{REFERENCES}

Ackerman, N. B., McFee, A. S., Bhum, J. A., Makowski, E. L., and Wangensteen, O. H. (1963). Multiple-organ cancer screening with diagnostic radioautographic procedures. J. Amer. med. Ass., 183, 36-39.

Bertalanffy, L. von, Masin, M., and Masin, F. (1958). A new and rapid method for diagnosis of vaginal and cervical cancer by fluorescence microscopy. Cancer (Philad.), 11, 873-887.

Kamen, M. D. (1951). Radioactive Tracers in Biology, 2nd ed. Academic Press, New York.

Pelc, S. R. (1956). The stripping film technique of autoradiography. Int. J. appl. Rad. Isot., 1, 172-177.

Raskin, H. F., Kirsner, J. B., Palmer, W. L., Pleticka, S., and Yarema, W. A. (1958). Gastrointestinal cancer. Arch. intern. Med., 101, 731-740. 